\title{
Cardiac damage in polymyositis associated with antibodies to tissue ribonucleoproteins
}

\author{
WILHELMINA M H BEHAN, * PETER O BEHAN, $†$ JAN GAIRNS \\ From the University Departments of $\star$ Pathology and $\dagger$ Neurology, Glasgow University, Glasgow
}

SUMMARY Cardiac damage, consisting of mild diffuse myocarditis or severe inflammation and $\mathcal{O}_{i}^{N}$ fibrosis of the conduction system or both, occurs in more than $70 \%$ of patients with idiopathic polymyositis. The lesions are strikingly similar to those detected in the infants of mothers with connective tissue diseases. In these infants the damage is associated with the transplacental pas-을 sage of a maternal antibody to tissue ribonucleoproteins (anti-Ro). The same antibody was $\vec{T}$ identified in $60 \%$ of 55 patients with polymyositis and in $69 \%(23 / 33)$ of those with associated $\Phi$ cardiac damage including four with complete heart block. Forty five per cent of those patients? who were anti-Ro seropositive had no clinical or electrocardiographic evidence of cardiac lesions. They were in the acute phase of illness, however, and no other more detailed heart investigations $\vec{\omega}$ had been done.

It is postulated that cardiac damage in polymyositis is caused by the antibody and that its presence may serve as a marker for heart involvement.

Polymyositis is an inflammatory myopathy of unknown cause in which both hormonal and cellular abnormalities occur that may be related to a defect in immunoregulation. ${ }^{12}$ Skeletal muscle bears the brunt of the disease but the skin (dermatomyositis), heart, lungs, eyes, and kidneys may also be affected. ${ }^{2}$ Cardiac lesions are of particular importance both because of their frequency, which has only recently been fully documented, and because they are one of the leading causes of death in this disease. ${ }^{3-5}$ Numerous published reports (reviewed by Askari and Huettner ${ }^{3}$ ) show that approximately $70 \%$ of cases of polymyositis have evidence of cardiac damage with the conduction system showing the severest lesions in one third of those affected. Complete heart block can occur and may cause sudden unexpected death. $^{5}$ In some cases, however, the lesions are confined entirely to the right or left bundle branch. The lesions found in the cardiac conduction system resemble those of the neonatal lupus syndrome, ${ }^{67}$ in which transplacental passage of a maternal autoantibody to tissue ribonucleoproteins (anti-Ro) seems to cause the damage. ${ }^{8}$ We have examined

Requests for reprints to Dr Wilhelmina M H Behan, Department of Pathology, Western Infirmary, Dumbarton Road, Glasgow G116NT.

Accepted for publication 11 November 1986 serum samples from a group of 55 well defined cases of polymyositis for anti-Ro.

\section{Patients and methods}

We examined serum samples collected from 55 patients with polymyositis over the past 10 years ato Glasgow hospitals. In each case the diagnosis was? based on clinical history, laboratory tests, electro-음 myography, and muscle biopsy examinations according to stated criteria. ${ }^{9}$ There were 17 male patients (aged 12-65 years, mean 38) and 38 women (aged 21-72 years, mean 46). They were classified? into subgroups ${ }^{9}$ as follows: subgroup $I$, pure poly $-\rightarrow$ myositis (13 cases); subgroup II, pure der-․․․ matomyositis (23 cases); subgroup III, polymyositis or dermatomyositis associated with neoplasia (two cases); subgroup IV, juvenile polymyositis or der-D matomyositis (six cases); and subgroup V, poly $-\omega$ myositis or dermatomyositis associated with otherर connective tissue diseases (11 cases). In the laste group there were four cases of the mixed connective tissue disease syndrome, three with rheumatoid arthritis, and one with severe Raynaud's phenomenon.

Sixteen patients were examined in the acute phase $\frac{?}{\rho}$ of the disorder, from six weeks to three months after? onset. In six of them a serum sample was obtaine of 
before treatment and in the other 10 it was collected after steroids had been given. The remaining 39 cases had had chronic active polymyositis for four months to 15 years. Thirty six were taking prednisolone $(5-10 \mathrm{mg} /$ day) and two of these were also on azothioprine $(100 \mathrm{mg} /$ day $)$. Three patients were taking no drugs.

\section{CARDIAC COMPLICATIONS}

All patients had had electrocardiograms but most had no other cardiac investigations (table 1 ).

The symptoms varied in degree from breathlessness on exertion to severe biventricular failure and included angina, dyspnoea, and palpitation; five patients had Adams-Stokes attacks. The most common electrocardiographic abnormalities were ST-T changes, right and left axis deviation, and abnormalities of the left atrial complex; but 13 patients had obvious evidence of conduction disorders-that is, five had complete heart block necessitating insertion of a pacemaker, four had right or left bundle branch block, and four had first degree heart block. Three of the patients with complete heart block died and in the two who came to necropsy there was almost complete fibrosis of the atrioventricular node with focal fibrosis of the bundle of $\mathrm{His}$ and the bundle branches; rare focal myocarditis was also present. The other two patients survived after the insertion of pacemakers. Two patients with right bundle branch block also died and necropsy confirmed focal fibrosis of the bundle, again accompanied by mild focal myocarditis and fibrosis. ${ }^{10}$

\section{CONTROL POPULATIONS}

Control serum samples were obtained from the following groups: (a) 100 normal healthy individuals; (b) $\mathbf{7 0}$ pregnant women attending an antenatal clinic; (c) 100 patients with other neuromuscular illnesses (multiple sclerosis, 60; myasthenia gravis, 25; alcoholic myopathy, five; intervertebral disc lesions, 10).

DETECTION OF ANTIBODIES

Serum samples were stored at $-70^{\circ} \mathrm{C}$ until use and

Table 1 Cardiac symptoms and electrocardiographic findings in 55 patients with polymyositis

\begin{tabular}{|c|c|}
\hline & $\begin{array}{l}\text { No of } \\
\text { cases }(\%)\end{array}$ \\
\hline $\begin{array}{l}\text { Dyspnoea, angina, palpitation, and/or heart failure } \\
\text { Electrocardiographic abnormalities: }\end{array}$ & $27(49)$ \\
\hline $\begin{array}{l}\text { Excluding conduction defects } \\
\text { With conduction defects }\end{array}$ & $\begin{array}{l}19(35) \\
13(24)\end{array}$ \\
\hline $\begin{array}{l}\text { Total with clinical signs and symptoms and/or } \\
\text { ECG findings }\end{array}$ & $35(64)$ \\
\hline
\end{tabular}

Table 2 Detection of anti-Ro in 55 cases of polymyositis

\begin{tabular}{lc}
\hline Patient group & $\begin{array}{l}\text { No of cases } \\
\text { positive }\end{array}$ \\
\hline Polymyositis & $33 / 55$ \\
Other neuromuscular diseases & $1 / 100$ \\
Normal pregnant women & $0 / 70$ \\
Normal healthy individuals & $0 / 100$ \\
\hline
\end{tabular}

then heat inactivated before testing. Antinuclear and anti-DNA antibodies were sought by standard indirect immunofluorescence techniques, with rat liver and Crithidia luciliae as the respective substrates. ${ }^{1112}$ Antibodies to soluble cellular antigens were detected by means of saline extracts of human spleen $^{13}$ (a potent source of the small ribosomal nucleoprotein, Ro antigen, as well as the other nucleoprotein complexes, Sm and nRNP) and fresh calf thymus, prepared as described for the human tissue. ${ }^{13}$ For each extract the serum was screened first by double immunodiffusion ${ }^{14}$ and then by counterimmunoelectrophoresis as outlined elsewhere. ${ }^{15}$ In the latter technique, known control antisera were incorporated and all positive results were confirmed by the demonstration of a complete reaction of identity with one of these known controls.

Positive anti-Ro antisera were obtained with the help of Dr P J Maddison, Dr G R V Hughes, and the Center for Disease Control, Atlanta; the CDC also supplied anti-La, anti-nRNP, and anti-Sm antisera (antisera to related non-histone extractable nuclear antigens).

The Ouchterlony plates were examined at 24,48 , 72 , and 96 hours whereas the plates produced on counterimmunoelectrophoresis were left overnight at room temperature, washed in 5\% citrate for four hours and then in phosphate buffered saline for $\mathbf{4 8}$ hours, and finally stained with Coomassie blue.

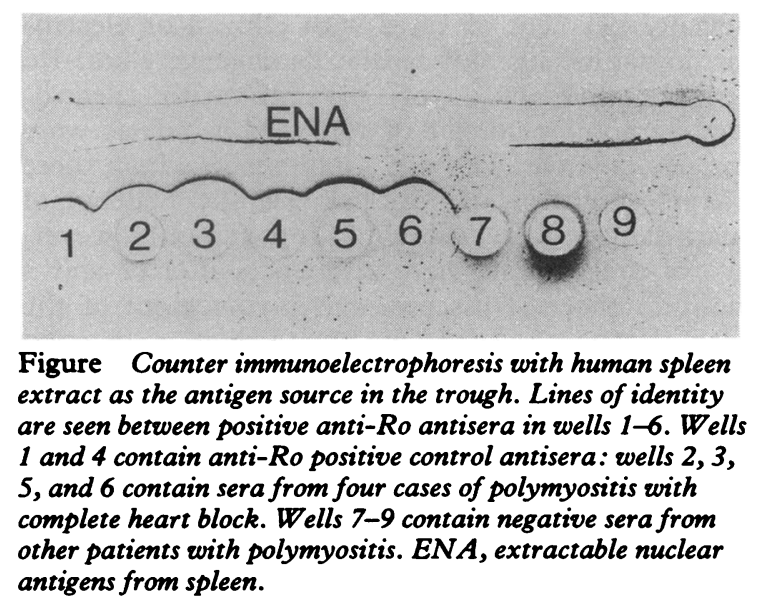


Table 3 Detection of anti-Ro in clinical subgroups of patients with polymyositis

\begin{tabular}{lc}
\hline & $\begin{array}{l}\text { No anti-Ro } \\
\text { seropositive } \\
\text { cases }\end{array}$ \\
\hline Subgroup & $6 / 13$ \\
\hline (I) Pure polymyositis & $15 / 23$ \\
(II) Pure dermatomyositis & $1 / 2$ \\
(III) Polymyositis/dermatomyositis associated & $2 / 6$ \\
with neoplasia & $9 / 11$ \\
(IV) Juvenile polymyositis/dermatomyositis & $33 / 55(60 \%)$ \\
(V) Polymyositis/dermatomyositis associated & \\
with connective tissue disease & \\
\hline
\end{tabular}

\section{Results}

Table 2 shows that $33(60 \%)$ of the 55 cases of polymyositis were seropositive for anti-Ro. The figure shows the positive results in four cases. One serum sample was anti-Ro positive in the control group of patients with other neuromuscular diseases; this patient had myasthenia gravis. Neither the normal pregnant women nor the healthy adult volunteers included any individuals with anti-Ro positive serum.

Table 3 shows the association of anti-Ro with the individual clinical subgroups. The highest percentage of anti-Ro positive sera $(82 \%)$ was found in subgroup $\mathrm{V}$-that is in patients in whom myositis was associated with another connective tissue disease. The next highest percentage was found in subgroup II (cases of dermatomyositis) in which 15 $(65 \%)$ of 23 serum samples were positive. In subgroup I (pure polymyositis) almost half of the patients were seropositive for anti-Ro, while among the juvenile cases there were two patients with antiRo positive sera, and in the neoplasia subgroup there was one.

Table 4 shows how the serological findings correlated with evidence of cardiac involvement. Seventy per cent of cases with clinical or electrocardiographic signs of cardiac damage were anti-Ro positive and $69 \%$ of patients with electrocardiographic evidence of conduction defects were anti-Ro positive. Ten of 22 patients in whom there was no clinical or electrocardiographic evidence of heart damage were also anti-Ro positive. However, two of the patients were seen soon after ( 2 and 3 months) onset of disease, and involvement of the heart may be a late phenomenon. Also more detailed tests might have revealed cardiac damage in these $\mathbf{1 0}$ patients.

Finally, patients who had electrocardiographic evidence of conduction disorders shown on the electrocardiogram were analysed separately (table 5). In the patients with the most severe damage, which led to complete heart block, four of the five sera tested
Table 4 Correlation between presence of anti-Ro and cardiac lesions in 55 cases of polymyositis

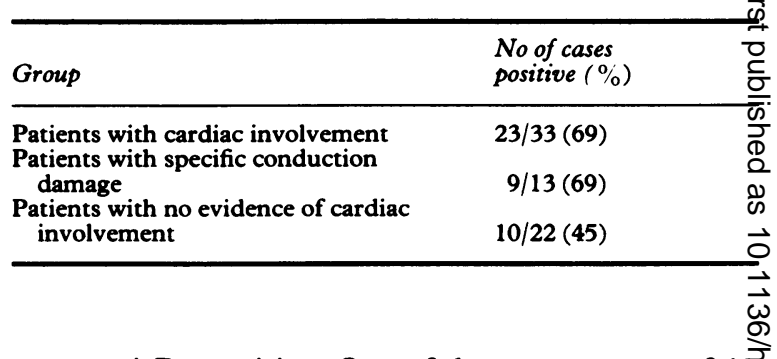

were anti-Ro positive. One of them was a man of 42 . with dermatomyositis, who was anti-Ro sero $y$ negative when he was first examined three monthọ after onset of disease. Two years later, when he com $=$ plained of weakness and breathlessness and needed insertion of a pacemaker, he was seropositive. The fifth serum was anti-La positive; the presence of this antibody may, rarely, mask the simultaneous pres $\oplus$ ence of anti-Ro. ${ }^{16}$ Three of the four patients with first degree heart block had anti-Ro and two of the four with bundle branch block lesions associated with polymyositis were also anti-Ro seropositive. Ofo the 13 patients with conduction disorders, therefore, nine (possibly 10) were anti-Ro seropositive.

Tests for antibodies to the other non-histone nucleoprotein antigens $\mathrm{La}, \mathrm{nRNP}$, and SM showed that 13 of the anti-Ro seropositive patients were alsळू positive for $\mathrm{La}$ antibodies while three patients ha\& anti-La alone. Anti-nRNP was detectable in the fou $\overrightarrow{5}$ patients with the mixed connective tissue syndromes and anti-Sm in one other case. Two of the precip? itating antibodies detected on the Ouchterlony? plates could not be identified. Antinuclear anti bodies were present at titres ranging from 1/64 (five cases) and $1 / 256$ (three cases) to $1 / 1000$ (eight cases) The serum samples with a titre of $1 / 1000$ all gave speckled appearance on immunofluorescence. $\mathrm{N} \dot{8}$ DNA antibodies were found and systemic lupus ery thematosus was not diagnosed in any patient.

\section{Discussion}

We have shown in this study that $60 \%$ of a large group of patients with polymyositis and $69 \%$ of

Table 5 Anti-Ro in patients with polymyositis and conduction disorders

\begin{tabular}{|c|c|}
\hline Conduction disorder & $\begin{array}{l}\text { No of anti-Ro } \\
\text { seropositive cases }\end{array}$ \\
\hline $\begin{array}{l}\text { Complete heart block } \\
\text { First degree heart block } \\
\text { Right bundle branch block } \\
\text { Left bundle branch block } \\
\text { Total }\end{array}$ & $\begin{array}{l}4 / 5 \\
3 / 4 \\
1 / 3 \\
1 / 3 \\
9 / 13(69 \%)\end{array}$ \\
\hline
\end{tabular}


those with associated cardiac damage had a antibody to tissue ribonucleoproteins (anti-Ro). Anti-Ro seropositivity is found in $0.1 \%$ of the normal population ${ }^{17}$ so that it was approximately 700 times more common in these patients with polymyositis and heart lesions, including conduction defects. Four of five patients with complete heart block had anti-Ro and the fifth had a high titre of anti-La (an antibody whose presence may interfere with detection of anti-Ro). ${ }^{16}$ Ten cases who were anti-Ro seropositive did not have clinical or electrocardiographic signs of heart damage. However, more sensitive methods of cardiac investigation would undoubtedly have revealed abnormalities, as has been shown conclusively in other series ${ }^{3}$; also heart damage tends to occur late. ${ }^{5}$ Thus it is possible that the antibody is present for some time before the tissue injury develops.

Heart lesions were originally thought to be very uncommon in polymyositis, but since the 1970s a large number of clinical and necropsy reports have shown that from $70 \%$ to $100 \%$ of these patients will have evidence of cardiac damage and that cardiac failure is the third leading cause of death. ${ }^{3-5} \mathrm{~A}$ whole range of heart abnormalities has been reported and damage to the conducting system results in various degrees of heart block in up to a third of patients. ${ }^{3}$ Sudden unexpected deaths occur because of this damage and the cardiac lesions may progress even when the skeletal muscle lesions are improving. ${ }^{5}$ This indicates the importance of identifying a possible marker (such as anti-Ro) for heart injury.

The cardiac lesions found in this disorder, and especially those affecting the conduction tissue, are the same in site, degree, and pathological features as those found in isolated complete congenital heart block. ${ }^{6-810}$ This is why we thought that the same pathogenetic agent might be active in both conditions. There is strong evidence for the pathogenetic role of anti-Ro antibody in complete congenital heart block. ${ }^{8161819}$ Concentrations of the Ro antigen, which has recently been purified and characterised $^{13}$ are highest in the heart and brain. ${ }^{20}$ This may explain the susceptibility of cardiac tissue to such damage. Mothers of affected infants, however, do not appear to develop heart lesions. ${ }^{16}$ An explanation for this is that only developing cardiac tissue is susceptible. The results of our study, however, show that adult cardiac cells can be severely damaged by anti-Ro. This may be because whereas the majority of the mothers are otherwise healthy, patients with polymyositis have such severe hormonal and cellular immunological abnormalities that, in the presence of these immune aberrations, cardiac myocytes and Purkinje fibres can be attacked. The HLA groups may also be important: anti-Ro was found in two of 10 cases of polymyositis associated with HLA-DR3. ${ }^{21}$ Other factors are fluctuations in antibody titre, which we noticed in two of our cases, and the hormonal milieu. All our patients with dermatomyositis, of whom $65 \%$ were anti-Ro seropositive, were female. As in the large series of congenital heart block, ${ }^{8}$ some of our patients also had antibodies to other soluble cellular antigens. Thirteen of the anti-Ro seropositive patients also had anti-La. Four anti-Ro seronegative patients had anti-RNP and one had anti-Sm.

An unexpected finding in our control group was that one of the 25 patients with myasthenia gravis, all of whom had heart disease associated with their myasthenia, was anti-Ro positive. These cases of myasthenia gravis were the subject of a recent review (J A Aarli, 1986, personal communication, and ${ }^{22}$ ). A larger series is now being examined to see whether anti-Ro is associated with cardiac damage in this other immune-mediated muscle disease.

Finally, to some extent our findings resemble those recently reported for a similar autoantibody, anti-Jo- $1 .^{23}$ Anti-Jo-1 was found in $25 \%$ of patients with myositis alone; however, $68 \%$ of patients with myositis and pulmonary damage were seropositive. Anti-Jo-1 has therefore been suggested as a useful indicator of cryptogenic fibrosing alveolitis in patients with myositis.

Our results indicate that a specific autoantibody known to be associated with cardiac damage is 700 times more common in patients with polymyositis and heart involvement than in the general population. We suggest that this antibody (anti-Ro) is a marker for cardiac injury in myositis and may indeed be the pathogenetic agent. A search for antiRo in patients with myositis may help to identify those at risk of sudden death from cardiomyopathy.

We thank clinicians from the Institute of Neurological Sciences, the Western and Royal Infirmaries, and Gartnavel General Hospital for allowing us access to their patients.

This work was supported by the Muscular Dystrophy Group of Great Britain.

\section{References}

1 Mastaglia FL, Ojeda VJ. Inflammatory myopathies: Part 2. Ann Neurol 1985;17:317-23.

2 Behan WMH, Behan PO. Immunological features of polymyositis/dermatomyositis. Springer Semin Immunopathol 1985;8:267-93.

3 Askari AD, Huettner TL. Cardiac abnormalities in polymositis/dermatomyositis. Semin Arthritis Rheum 1982;12:208-19.

4 de Vere R, Bradley WG. Polymyositis: its presentation, 
morbidity and mortality. Brain 1975;98:637-66.

5 Stern R, Godbold JH, Chess Q, Kagen LJ. ECG abnormalities in polymyositis. Arch Intern Med 1984;144:2185-9.

6 Carter JB, Blieden LC, Edwards JE. Congenital heart block: anatomic correlations and review of the literature. Arch Pathol 1974;97:51-7.

7 Vetter VL, Rashkind WJ. Congenital complete heart block and connective tissue disease. $N$ Engl $\mathcal{F}$ Med 1983;309:236-7.

8 Scott JS, Maddison PJ, Taylor PV, Esscher E, Scott O, Skinner RP. Connective-tissue disease, antibodies to ribonucleoproteins, and congenital heart block. $N$ Engl f Med 1983;309:209-12.

9 Bohan A, Peter JB. Polymyositis and dermatomyositis. $N$ Engl f Med 1975;292:344-7; 403-7.

10 Behan WMH, Aitchison M, Behan PO. Pathogenesis of heart block in a fatal case of dermatomyositis. $\mathrm{Br}$ Heart $\mathcal{f} 1986 ; 56: 479-82$.

11 Holborow EJ, Weir DM, Johnson GD. A serum factor in lupus erythematosus with affinity for tissue nuclei. Br Med F 1957;ii:732-4.

12 Aarden LA, de Grott ER, Feltkamp TEW. Immunology of DNA. III. Crithidia luciliae: a simple substrate for the determination of anti-dsDNA with the immunofluorescence technique. Ann NY Acad Sci 1975;254:505-14.

13 Venables PJW, Smith PR, Maini RN. Purification and characterization of the Sjögren's syndrome A and B antigens. Clin Exp Immunol 1983;54:731-8.

14 Venables PJW, Mumford PA, Maini RN. Antibodies to nuclear antigens in polymyositis: relationship to autoimmune "overlap syndromes" and carcinoma.
Ann Rheum Dis 1981;40:217-23.

15 Bunn CC, Gharavi AE, Hughes GRV. Antibodies to extractable nuclear antigens in 173 patients with ${ }^{\text {? }}$ DNA-binding positive SLE: an association between? antibodies to ribonucleoproteins and $\mathrm{Sm}$ antigens observed by counter immunoelectrophoresis. f Clin? Lab Immunol 1982;8:13-7.

16 Lee LA, Weston WL. New findings in neonatal lupuse syndrome. Am $\mathcal{f}$ Dis Child 1984;138:233-6.

17 Tan EM. Autoantibodies to nuclear antigens (ANA): their immunobiology and medicine. Adv Immunol 1982;233:167-241.

18 Litsey SE, Noonan JA, O'Connor WM, Cottrill CM, Mitchell B. Maternal connective tissue disease and? congenital heart block. $N$ Engl $f$ Med 1985; $N$ 312:98-100.

19 Taylor PV, Scott JS, Gerlis LM. Maternal connective tissue disease and congenital heart block [Letter]. $N^{\circ}$ Engl f Med 1985;312:1328-9.

20 Wolin SL, Steitz JA. The Ro small cytoplasmic ribo-nucleoproteins: identification of the antigenic protein $T$ and its binding site on the Ro RNAs. Proc Natl Acado Sci USA 1984;81:1996-2000.

21 Arnett FC, Hirsch TJ, Bias WB, Nishikai M, Reichlin $M$. The Jo-1 antibody system in myositis: relationships to clinical features and HLA. $\mathcal{F}$ Rheumatolos 1981;8:925-30.

22 Hofstad H, Ohm O-J, Mark SJ, Aarli JA. Heart disease in myasthenia gravis. Acta Neurol Scand 1984; 70:176-84.

23 Bernstein RM, Morgan SH, Chapman J, et al. Anti-Jo-岗 1 antibody; a marker for myositis with interstitialक lung disease. $\mathrm{Br} M e d$ F 1984;289:151-2. 